\title{
Geotourism Potentiality of the Rarh Region of West Bengal: A Geographical Outlook
}

\author{
*Mandal, Tushar \\ *Assistant Professor \& Head, Department of Geography, Saltora Netaji Centenary College, Saltora, Bankura, \\ West Bengal-722 158 India
}

\begin{abstract}
Geotourism is currently being considered as one of the most promising sectors of tourism and is being practiced by many countries rich in this kind of tourism resource. India, as well as one of its easternmost states- West Bengal is blessed with bundreds of such tourism resources. It is being considered as a bright name in the geotourism map of India, drawing few domestic and international visitors. Through the present study, the author has attempted to make an inventory of notable geotourism destinations of Rarh region of West Bengal while assessing their tourism potentiality, strength, opportunity and threat applying the SWOT-AHP analysis of Saaty (1990). It has been inferred that this region has great potential to become a geotourism hotspot in the near future if sustainable planning measures are taken.
\end{abstract}

Keywords: Geotourism, Rarh region, SWOT-AHP, sustainable, potentiality

\section{Article Publication}

Published Online: 15-Dec-2021

\section{*Author's Correspondence}

8 Tushar Mandal

8 Assistant Professor \& Head, Department of Geography, Saltora Netaji Centenary College, Saltora, Bankura, West Bengal-722 158 India

$\square$ tushargeoindia[at]gmail.com

C 2021 The Author. Published by RESEARCH REVIEW International Journal of Multidisciplinary. This is an open access article under the CC BY-

NC-ND license

(https://creativecommons.org/licenses/ by-nc-nd/4.0/)

\section{Introduction}

Geotourism is a special type of new niche tourism activity that has grown to be quite popular among both the allocentric and psychocentric travelers throughout the world. It actually is a specialized form of tourism activity that puts focus on the economic utilization of the geosites i.e. sites with remarkable natural geological features. The term 'geotourism' has first been used by Thomas A. Hose -a Professor of earth science of the University of Bristol in the year 1995 (Mahato \& Jana, 2021) who, along with his associate researcher D. A. Vasiljevic has defined geotourism as a "provision of informative and service facilities for geosites and geomorphosites and their surrounding topography together through their allied in-situ and ex-situ artifacts, to build of constituency for their conservation by making appreciation, learning and research for current and future generations" (Hose \& Vasiljevic, 2012). Hose is also of the opinion that geotourism aims to ensure the social preservation of the geological and geomorphological sites and to provide interpretative facilities and services for the use of students, tourists and other casual recreationalists (Hose, 2005). According to Newsome \& Dowling (2010), Geotourism is "a form of nature tourism that specifically focuses on landscape and geology. It promotes tourism to the geosites and the conservation of geodiversity, and an understanding of earth sciences through appreciation and learning. This is achieved through independent visits to geological features, use of geo-trails and viewpoints, guided tours, geo-activities and patronage of geosite visitor centres". Geotourism is actually a special kind of tourism that sustains or enhances the geographical character of a place-its environment, culture, aesthetics, heritage, and the well-being of its residents (National Geographic Society, 2021). It is an environmentally innovative, emerging type of tourism that within a short span of time has been able to draw the attention of many travellers, preserving the valuable geodiversity with a keen understanding of earth science. Geotourism may be described as multifaceted tourism because it has several aspects with diversified goals underlining the concept (Swarna et al., 2013). In a broader 
sense, geoheritage also includes cultural sites (such as mining sites)/archaeological sites (made of stones) that have an integrated value in response to a particular region. Preservation of natural heritage and associated cultural values to education, interpretation and entertainment is the main aim of Geotourism (Gordon, 2018). This special type of responsible tourism activity helps visitors understand the geomorphic processes, the geological history, development and evolution of landforms of any place. Geotourism eventually has emerged as a path of attaining sustainability of vulnerable geomorphosites needs to be conserved immediately. The term 'geomorphosite' was first used by M. Panizza in the year 2001. According to him, geomorphosites are those geomorphological landforms that possess scientific, aesthetic, cultural, and socio-economic values due to human perception. (Panizza, 2001).

Reynard et. al. (2004), on the other hand, is of the opinion that geomorphosites are those "landforms that have particular importance for the knowledge of earth history that means these landforms can help us to analyse the temporal evolution of an area." A typical example of geomorphosite or geosite may refer to a rock outcrop, a fossil park, a karst landscape, a badland topography, residual hill etc. Nowadays, it has been observed that these valuable geotourism resources are under threat due to human intervention, and many of them are on the brink of being extinct forever. Here raises the need for effective geoconservation, which is the act of protecting geosites and geomorphosites from damage, deterioration, or loss through the implementation of protection and management measures (Hose, 2012). By far, the most efficient way to promote geoconservation is through geotourism (Newsome \& Dowling, 2010).

\section{Major Objectives:}

The major objectives of the present study include:

1. To explore the typology of major geosite/geomorphosite of Rarh region of West Bengal

2. To evaluate the geotourism potentiality of the geosites.

3. To propose appropriate strategies for the conservation of the geosites and promote sustainability in the tourism sector.

\section{Study Area:}

India is characterized by intriguing geological history, which is evident in its large number of magnificent and interesting geological features dotted all over the subcontinent. The most important geosites of India (which have been recognized as 'National Geological Monuments' by the Geological Survey of India) include Marine Gondwana Fossil Park in Chhattisgarh, Akal Fossil Wood Park in Rajasthan, Great Boundary Fault at Satur in Rajasthan, Pillow Lava, Iron Ore Belt etc. The Rarh region of West Bengal has been chosen as the study area for the present study because of the abundance of such valuable geomorphosite/geosites of a high level of tourism potentiality. The Rarh region is one of the three broad physiographic regions/divisions of West Bengal. It extends between $21^{\circ} 30^{\prime} 26^{\prime \prime} \mathrm{N}$ to $24^{\circ} 54^{\prime} 14^{\prime \prime} \mathrm{N}$ latitude and $85^{\circ} 58^{\prime} 48^{\prime \prime} \mathrm{E}$ to $88^{\circ} 30^{\prime} 10^{\prime \prime} \mathrm{E}$ longitude. The word 'Rarh' has its origin from a Sanskrit word 'Roorha', meaning rough or uneven. The study region is situated in between Chotanagpur Plateau (on the west) and River Ganges (in the east).

\section{Materials and Methods:}

The entire methodology has been divided into two successive sections. Both qualitative and quantitative approaches have been adopted in order to assess the tourism potentiality of the geosites and also to find out the significant strength, weakness, opportunity and threat factors which have been done using SWOT-AHP analysis following the method of Saaty (1990). In this analysis, strengths factors are the internal inherent positive factors of the geosites, weakness are internal negative factors that can be considered as major bottlenecks in the development. Opportunity factors are the external favorable conditions and scope that the geosites possess, whereas threat factors are the external negative factors that pose as barriers in the path of development. Hierarchical construction of SWOT matrix is done where each factor is subjected to pairwise comparison through focus group survey. These multiple pairwise comparisons have been based on a nine-point scale of relative importance which can be represented by a square or reciprocal matrix. Digital cartographic techniques have been 
used to present relevant information, and a map has been generated with the help of QGIS software to show the location of various major geosites of the study area.

\section{Geotourism Resources of the Rarh Region:}

Being an extension of the Chottanagppur Plateau, the Rarh region of West Bengal has many important geosites, which are as follows:

\section{Amkhoi Fossil Park (23037'52' N, 87035'13" E):}

Amkhoi Fossil Park is the first fossil park in Eastern India which contains a large number of dendro fossils collected from the surrounding area. It is located in Amkhoi village of Illambazar subdivision of Birbhum district. This fossil park is just $11 \mathrm{~km}$ away from Santiniketan-an international cultural tourism destination. The dendrofossils which were discovered in the surroundings of Amkhoi village are in fact angiosperm wood fossil whose origin dates back to the Late Miocene period at about 15-20 million years ago. Due to natural calamities, the lush green deciduous forest was buried under fine sand and clay and ultimately has been transformed into fossils. This park has been set up recently by the Directorate of Forest, Government of West Bengal, in collaboration with the local predominantly tribal community.

\section{Major Geotourism Destinations of the Rarh Region of West Bengal}

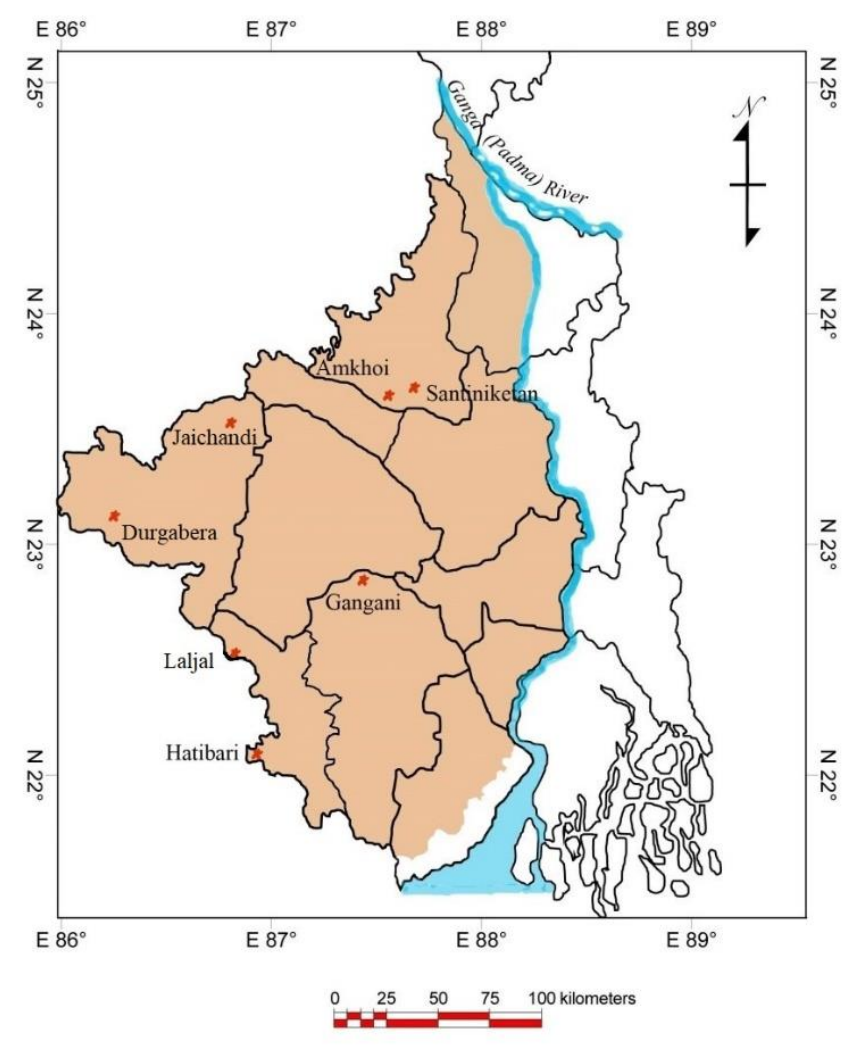

Source: Prepared by the author

Khoai (badlands), Santiniketan:

Badlands are degraded landscapes cut and eroded by many deep, tortuous gullies with intervening saw-toothed divides (Encyclopaedia Britannica, 2016), minimal vegetation, and lack of a substantial regolith. These are formed by the continuous action of wind and water through the ages. Badlands are widely available and have won recognition as a natural heritage in many countries of the world including United States, Mexico, Canada, New Zealand, Italy etc. The term 'Khoai' was given by the Nobel Laureate poet Rabindranath Tagore to denote khoi i.e. 
erosion of the land. It is situated at a distance of only $4 \mathrm{~km}$ from Visva Bharati- Tagore's dream project consisting of a school and a university of international reputation. Khoai attracts a large number of tourists, nature lovers, artists as well as researchers- both domestic and international throughout the year. The students of Kala Bhavan (the world-famous art department of Visva-Bharati) have curved many sculptures on the wall of the Khoai, which is an added attraction besides its outstanding natural beauty.

The Khoai have archaeological importance too, as a number of Acheulian and Middle Palaeolithic sites and Mesolithic sites have been discovered here due to which Khoai has been recognized as one of the cultural corridors in the Stone Ages (INTACH, 2014). Unfortunately, this natural heritage of Bengal has been under threat from rapid urbanization, land encroachment, and land conversion since the 2000s. Unauthorized hotels have sprouted up rapidly here and there over the Khoai, destroying the landscape. Pollution is rampant nowadays. That iconic, dusty red road to Khoai, which was mentioned by Tagore in one of his timeless poems, has recently been converted into a black metalled road which has affected the serene environment of Khoai and lowered its appeal. Besides, different types of anti-social activities have increased to a great extent. A large amount of garbage, including plastics, bottles of alcohol, and human wastes, are strewn in many parts of the area responsible for land and soil pollution.

\section{Gangani-Garhbeta (22051'28" N, 87020' 22" E):}

The badland topography of Garhbeta (50 km from Kharagpur) of Paschim Medinipur district, is known as the Grand Canyon of Bengal. The magnificent badland topography is situated on the bank of River Shila, covering an area of $3.5 \mathrm{sq} \mathrm{km}$. Without any doubt, it is the most famous geotourism site of West Bengal and one of the important ones in Eastern India (Chakrabarty \& Mandal, 2018). But due to the indifference of the administration and lack of consciousness amongst local people, this striking geotourism site is merely being used as nothing but a picnic spot and grazing ground for their domestic animals. Besides being a geomorphosite, this place also has significant historical value as this place once was the playground of 'Chuar Rebellion' under the leadership of local Zamindar Durjan Singha of Raipur.

\section{Hatibari (22029'30" N, 8700'21" E):}

Hatibari on the bank of river Subarnarekha is a prominent geosite of this region. A large number of exposed rock outcrops and natural rock sculptures can be found in Hatibari, which is quite attractive and attracts some tourists throughout the year especially in the winter season. Its outstanding scenic beauty is another added attraction. One can see somewhat decayed and demolished infrastructure in this site which was once destroyed during the period of political turmoil relating to Maoist movement in the long past. The situation nowadays has changed completely, which has increased the tourism potentiality of this place to a great extent.

\section{Jaichandi granitoid batholith:}

Jaichandi is a notable batholith having a continuous intrusive granitic body of late Proterozoic era. It is situated in the district of Puruliya near North Puruliya Shear Zone (NPSZ) (Ghosh, Mukhopadhyay \& Chatterjee, 2021). This giant porphyritic granitoid batholith is formed by mixing mantle-derived mafic magma and crustal melts in continent-continent collisional settings (Goswami \& Bhattacharyya, 2008). In the midst of the structure, pegmatite veins are common. Jaichandi is an important geomorphosite having a high degree of the potentiality of initiating geotourism. At the pedestal of the domes, blockfield or felsenmer, which are actually the deposit of large rock blocks, can be seen. These are basically formed due to mechanical weathering as a result of intensive heating during the day and cooling at night.

\section{Laljal cave:}

Laljal is another geosite though comparatively of smaller dimensions but is an important one which was of granite and gneiss rocks. It is also known as a notable archaeological site as clear traces of cave painting of Mesolithic and 
Neolithic eras along with the traces of habitation of our predecessors of the prehistoric era have been found. Extensive mechanical weathering and its resultant landform are evident here.

\section{Durgabera dam:}

Durgabera dam is popularly known as Marble Lake to the locals. This is actually an artificially created lake and one of the most important geosite of Rarh region of West Bengal where one can see a varying number of beautiful folds, dykes, sills, and crystallized mineral veins. The lithology of this place contains a diversified range of rocks ranging from high-grade metamorphic rocks to younger dolerite intrusions due to which it can be called as a museum of precambrian geology. Metamorphic rocks in this site essentially include hornblende gneiss composed chiefly of hornblende and biotite with accessory opaque minerals (Ghosh, Mukhopadhyay \& Chatterjee, 2021).

\section{Discussion and Analysis:}

In order to assess the status of geotourism activities in the study area, a SWOT (Strength, Weakness, Opportunity \& Threat) analysis was undertaken by the present scholar. It was to analyze the internal strength and internal weaknesses of the budding tourism industry and also to highlight the opportunities and threats of the external environment in the present context. SWOT analysis is widely considered an efficient tool for successful strategy formulation and decision-making.

The SWOT factors (table 1) taken into consideration as follows:

Table 1 Different SWOT factors regarding the geotourism industry of Rarh region.

\section{SWOT}

\begin{tabular}{|c|c|}
\hline S (Strength) & W (Weakness) \\
\hline 1. Accessibility to the geosites & 1. Lack of exposure \\
\hline 2. History, culture, and natural heritage & 2. Infrastructural bottleneck \\
\hline 3. Behaviour of the resident populations & 3. Less community involvement \\
\hline 4. Presence of other recognized sites in the region & $\begin{array}{l}\text { 4. District-based tourism planning instead of } \\
\text { geographical region based planning }\end{array}$ \\
\hline O (Opportunity) & T (Threat) \\
\hline 1. Unexplored geosites with huge potentialities & 1. Mass tourism phenomenon \\
\hline 2. Development of demand-based circuits & 2. Inefficient management of geotourism resources \\
\hline 3. Better safety perception among travelers & 3. Landscape degradation \\
\hline $\begin{array}{l}\text { 4. Government policy of identifying tourism as an } \\
\text { instrument of backward area develonment }\end{array}$ & 4. Cultural pollution \\
\hline
\end{tabular}

The results of the SWOT-AHP calculation have been represented through the following table:

Table 2 Final Pair-Wise Comparison Matrices for SWOT Factors

\begin{tabular}{|c|c|c|c|c|c|c|}
\hline $\begin{array}{l}\text { SWOT } \\
\text { Groups }\end{array}$ & Strength & S1 & S2 & S3 & S4 & $\begin{array}{c}\text { Priorities of SWOT } \\
\text { factors/Local Weight }\end{array}$ \\
\hline \multirow{5}{*}{ Strength (S) } & S1: Accessibility to the geosites & 1 & 2 & 1 & $1 / 2$ & 0.247168 \\
\hline & S2: History, culture, and natural heritage & & 1 & $1 / 3$ & 1 & 0.151506 \\
\hline & S3: Behaviour of the resident populations & & & 1 & 2 & 0.381319 \\
\hline & $\begin{array}{l}\text { S4: Presence of other recognized sites in the } \\
\text { region }\end{array}$ & & & & 1 & 0.249011 \\
\hline & \multicolumn{6}{|c|}{ Maximum Eigen Value $=4.23691$ C.I. $=0.089955$ CR $=0.099868801$} \\
\hline $\begin{array}{l}\text { SWOT } \\
\text { Groups }\end{array}$ & Weakness & W1 & W2 & W3 & W4 & $\begin{array}{c}\text { Priorities of SWOT } \\
\text { factors/Local Weight }\end{array}$ \\
\hline \multirow{4}{*}{$\begin{array}{l}\text { Weakness } \\
\text { (W) }\end{array}$} & W1: Lack of exposure & 1 & $1 / 2$ & 4 & $1 / 2$ & 0.255741 \\
\hline & W2: Infrastructural bottleneck & & 1 & 4 & 2 & 0.428984 \\
\hline & W3: Less community involvement & & & 1 & $1 / 4$ & 0.0741234 \\
\hline & W4: District-based tourism planning instead of & & & & 1 & 0.27777 \\
\hline
\end{tabular}




\begin{tabular}{|c|c|c|c|c|c|c|}
\hline \multirow{3}{*}{$\begin{array}{l}\text { SWOT } \\
\text { Groups }\end{array}$} & geographical region based planning & & & & & \\
\hline & \multicolumn{6}{|c|}{ Maximum Eigen Value $=4.32156$ C.I. $=0.0404404 \quad \mathrm{CR}=0.044933489$} \\
\hline & Opportunities & O1 & $\mathbf{O} 2$ & $\mathbf{O 3}$ & $\mathbf{O} 4$ & $\begin{array}{c}\text { Priorities of SWOT } \\
\text { factors/Local Weight }\end{array}$ \\
\hline \multirow{5}{*}{$\begin{array}{l}\text { Opportunities } \\
\text { (O) }\end{array}$} & $\begin{array}{l}\text { O1: Unexplored geosites with huge } \\
\text { potentialities }\end{array}$ & 1 & 3 & $1 / 2$ & 1 & 0.244467 \\
\hline & O2: Development of demand-based circuits & & 1 & $1 / 2$ & $1 / 2$ & 0.13322 \\
\hline & O3: Better safety perception among travelers & & & 1 & $1 / 2$ & 0.278498 \\
\hline & $\begin{array}{l}\text { O4: Government policy of identifying tourism } \\
\text { as an instrument of backward area } \\
\text { development }\end{array}$ & & & & 1 & 0.333554 \\
\hline & \multicolumn{6}{|c|}{ Maximum Eigen Value $=4.24199$ C.I. $=0.0807755 \quad \mathrm{CR}=0.089972788$} \\
\hline $\begin{array}{l}\text { SWOT } \\
\text { Groups }\end{array}$ & Threat & T1 & T2 & T3 & T4 & $\begin{array}{c}\text { Priorities of SWOT } \\
\text { factors/Local Weight }\end{array}$ \\
\hline \multirow{5}{*}{ Threat (T) } & T1: Mass tourism phenomenon & 1 & $1 / 5$ & 2 & 3 & 0.199003 \\
\hline & $\begin{array}{l}\text { T2: Inefficient management of geotourism } \\
\text { resources }\end{array}$ & & 1 & 5 & 6 & 0.608315 \\
\hline & T3: Landscape degradation & & & 1 & 4 & 0.139814 \\
\hline & T4: Cultural pollution & & & & 1 & 0.0513221 \\
\hline & \multicolumn{6}{|c|}{ Maximum Eigen Value $=4.24531$ C.I. $=0.079441 \mathrm{CR}=0.088274434$} \\
\hline
\end{tabular}

Calculation also has been done to find out the global priority of the SWOT factors, which are as follows:

Table 3 Final Pair-Wise Comparison Matrices for SWOT Groups

\begin{tabular}{|l|c|c|c|c|c|}
\hline \multicolumn{1}{|c|}{ SWOT Groups } & Strength & Weakness & Opportunities & Threat & Weight \\
\hline Strength & 1 & $1 / 4$ & $1 / 4$ & 2 & 0.126864 \\
\hline Weakness & & 1 & 1 & 3 & 0.379022 \\
\hline Opportunities & & & 1 & 3 & 0.383022 \\
\hline Threat & & & 1 & 0.101997 \\
\hline Maximum Eigen Value $=4.12242$ C.I. $=0.0407701 \quad$ CR= 0.044400114 \\
\hline
\end{tabular}

Table 4 Factor Priority Scores and Overall or Global Priority Scores of SWOT Factors

\begin{tabular}{|c|c|c|c|c|}
\hline SWO'T Groups & Groups Priority & Factors & Local Priority & Global Priority \\
\hline \multirow{4}{*}{ Strength } & \multirow{4}{*}{0.126961} & S1 & 0.247168 & 0.030988516988 \\
\hline & & S2 & 0.151506 & 0.019023568678 \\
\hline & & S3 & 0.381319 & 0.045666761167 \\
\hline & & S4 & 0.249011 & 0.029998189171 \\
\hline \multirow{4}{*}{ Weakness } & \multirow{4}{*}{0.388022} & W1 & 0.255741 & 0.080755099582 \\
\hline & & W2 & 0.428984 & 0.161810149164 \\
\hline & & W3 & 0.0741234 & 0.0277711937555 \\
\hline & & W4 & 0.27777 & 0.11321112902 \\
\hline \multirow{4}{*}{ Opportunities } & \multirow{4}{*}{0.388021} & O1 & 0.244467 & 0.099899628828 \\
\hline & & $\mathrm{O} 2$ & 0.13322 & 0.04698886284 \\
\hline & & O3 & 0.278498 & 0.110307369458 \\
\hline & & $\mathrm{O} 4$ & 0.333554 & 0.127827891874 \\
\hline
\end{tabular}




\begin{tabular}{|l|c|c|c|c|}
\hline \multirow{3}{*}{ Threat } & \multirow{3}{*}{0.111195} & T1 & 0.199003 & 0.018713666785 \\
\cline { 3 - 4 } & & T2 & 0.608315 & 0.063055577175 \\
\cline { 3 - 4 } & & T3 & 0.139814 & 0.01455657778 \\
\cline { 3 - 4 } & & T4 & 0.0513221 & 0.0062444083195 \\
\hline
\end{tabular}

Source: Author [Result derived from SWOT - AHP Combined Methodology, after Saaty (1990) ]

Having made all the primary pair wise comparison, a final pair-wise comparison matrix has been calculated from which the consistency of the data. After that, the Consistency Ratio (CR) by using the 'AHP Calculation Software' has also been calculated. The result shows that among the local weights or eigen values of the four Strength factors, S3 i.e. Behaviour of the resident populations is the most significant factors followed by S4 (0.249011), S1 (0.247168) and S2 (0.151506). Among the four Weakness factors, W2 i.e. Infrastructural bottleneck, is most significant followed by W4 (0.27777), W1 (0.255741) and W3 (0.0741234). The eigen values of four Opportunity factors show that, $\mathrm{O} 4$ i.e. Unexplored geosites with huge potentialities with an eigen value of 0.333554 is the most significant factor, followed by O3 (0.278498), O1 (0.244467), and O2 (0.13322). Among the four threat factors, T2 (Inefficient management of geotourism resources) has acquired the most significant status with an eigen value of 0.608315 followed by T1 (0.199003), T3 (0.139814) and T4 (0.0513221).

For deriving the global priority scores of the SWOT Factors, the eigen values of each of the SWOT factors (i.e. Strength, Weakness, Opportunity and Threat) have been multiplied by the group priority values. The result shows that among the above-mentioned four factors, Opportunity factors are the most significant factors. Weakness factors have a little less share than that of the Opportunity factors, followed by the Strength factors and Threat factors.

\section{Conclusion:}

The Rarh region of West Bengal, from an economic perspective, is backward as neither agriculture nor industry has developed to a considerable extent. But the area is blessed with a large number of geosites and other tourism resources based on which the region can prosper tremendously. The present study shows that the tourism potentiality of these valuable resources is very high. Geotourism is an essential tool that can be instrumental in the sustainable development of the study area, but it is necessary to put earnest effort into identifying and neutralizing the major bottlenecks affecting the region negatively. Stronger coordination between the administration and the local community in the form of a public-private partnership is very much needed for the sustainable geotourism development in the study area.

\section{Reference:}

Chakrabarty, P. \& Mandal, T. (2018). Tourism and sustainability: a geographical study in the Rarh Region of West Bengal. In: Shukla, P., Shukla, P., Chakrabarty, P. \& Dey, N., Sustainable Development: A Dynamic Perspective. Kolkata: Anjan Pub.

file://C:/Users/User/Downloads/TourismandSustainability_AGeographicalStudyintheRarhRegionofWestBengal. pdf

Ghosh, A. Mukhopadhyay, S \& Chatterjee, S. (2021). Assessment of geoheritage and prospects of geotourism: An approach to geoconservation of important geological and geomorphological sites of Puruliya district, West Bengal, India. International Journal of Geoheritage \& Park, 9(2). https://doi.org/10.1016/j.ijgeop.2021.03.001

Gordon, J. E. (2018). Geoheritage, geotourism and the cultural landscape: enhancing the visitor experience and promoting geoconservation. Geosciences, 8, 136. doi:10.3390/geosciences 8040136

Hose, T.A. (2012) 3G's for modern geotourism. Geoh 4(1-2):7-14. https://doi.org/10.1007/s12371-011-0052-y 
Hose, T. A. (2005). Geo-Tourism-Appreciating the deep side of landscapes in Novelli. Niche tourism; contemporary issues, trends and cases. Oxford, UK: Elsevier Science Ltd, 27-37https://silo.pub/niche-tourism-contemporaryissues-trends-and-cases.html.

Hose, T. A., \& Vasiljevic, D. A. (2012). Defining the nature and purpose of modern geotourism with particular reference to the United Kingdom and South-East Europe. Geoheritage, 4, 25-

43.https://www.nationalgeographic.com/maps/topic/geotourism_Retreived on 28-09-2021

INTACH, (2014). Santiniketan chapter. Retrieved from http://documentationcentre.intach.org/wpcontent/uploads/2018/06/Annual-Report-2015-16

Mahato, M. K., \& Jana, N. C. (2021). Exploring the potential for development of geotourism in Rarh Bengal, Eastern India using M-GAM. International Journal of Geoheritage and Parks, 9(3), 313-322. https://doi.org/10.1016/J.IJGEOP.2021.05.002

Newsome, D., \& Dowling, R. K. (Eds.). (2010). Geotourism: The tourism of geology and landscape. Oxford: Goodfellow Publishers.

Panizza M (2001) Geomorphosites: concepts, methods and examples of geomorphological survey. Chin Sci Bull 46:4-5. https://doi.org/10.1007/BF03187227

Panizza, M. (2001). Geomorphosites: Concepts, methods and examples of geomorphological survey. Chinese Science Bulletin 2001 46:1, 46(1), 4-5. https://doi.org/10.1007/BF03187227

Reynard E (2004) Geosite. In: Goudie AS (ed) Encyclopedia of geomorphology, 1st edn. Routledge, London, p 440

Reynard, E., Fontana, G., Kozlik, L., and Scapozza, C. (2007). A method for assessing "scientific" and "additional values" of geomorphosites, Geogr. Helv., 62, 148-158, https://doi.org/10.5194/gh-62-148-2007.

Saaty, T.L. (1990) The Analytic Hierarchy Process: Planning, Priority Setting, Resource Allocation, McGraw-Hill, Inc.

Swarna, K., Biswas, S. K., \& Harinarayana, T. (2013). Development of Geotourism in Kutch Region, Gujarat, India: An Innovative Approach. Journal of Environmental Protection. https://doi.org/10.4236/jep.2013.412157 